MIRKO RAGUŽ

\title{
ŠKOLE SENJSKOG PODGORJA
}

Mirko Raguž

Ivana Lenkovića 24

HR 53270 Senj

mirko.raguz2@inet.hr
UDK: 373.3(497.5 Senj)(091)

Pregledni članak

Ur.: 2016-12-18

Na području senjskog Podgorja pučko je školstvo u prošlosti bilo dosta dobro razvijeno, tako da gotovo u svim mjestima i naseljima mjesne vlasti su uz pomoć nadležnih političkih i prosvjetnih institucija otvarali najprije četverorazredne, a potom i šestorazredne, odnosno osmorazredne osnovne škole. Njihovo prosvjetno djelovanje ovisilo je najviše od materijalnih i prostornih mogućnosti, ali kasnije i brojčanog stanja polaznika u pojedinim naseljima. Put od otvaranja do konačnog njihova zatvaranja u nekim sredinama nije bio dug. O svemu tome ukratko će biti predstavljene sve škole od otvaranja do konačnog njihova prestanka s radom sa svim relevantnim podatcima do kojih sam došao u skromnoj školskoj dokumentaciji. Temeljitije i opširnije sam o podgorskim pučkim školama pisao i objavio u knjizi pod naslovom Školstvo senjskog Podgorja u nakladi Matice hrvatske Senj, godine 2008. O njima ima temeljitije stručno i znanstveno predstavljeno sa svim pojedinostima, školama, učiteljima i učenicima u senjskim zbornicima 13, 17, 20, 21 i 22. $\mathrm{U}$ dodatnim istraživanjima na ovu temu u pripremi za znanstveni skup o Podgorju u ovom radu malo je novijih podataka, jer su prethodno temeljito obrađene sve podgorske škole. škola

Ključne riječi: Podgorje, škole, prve škole, učitelji, učenici, standard učitelja, zatvaranje

\section{Uvod}

U zadnja tri stoljeća po dolasku prebjega iz Dalmacije u područja senjskog Podvelebitja nije se razvila ni jedna srednja škola, ali je u tome razdoblju djelovalo 13 pučkih škola, i to: Sv. Juraj (1775-), Jablanac (1825-2007), Lukovo (1894-1969), Oltari (1903-1977), Starigrad (1900-1945), Gornji Starigrad (19451967), Bilopolje (1939-1967), Brisnice (1926-1959), Prizna (1908-1977), Donja Klada (1929-1949), Dundović Pod (1946-1959), Vlaka (1948-1968), Dušikrava (1947-1961), od kojih je danas ostala samo jedna, i to ona u Sv. Jurju. Neki izvori upućuju da je još 1733. u Sv. Jurju djelovala neka vrsta škole. U izvješću 
te župe iz godine 1733. stoji: "Ludi magistri non dantur sed parochus solus gratis instruit iuventutem" Župnik te župe Nikola Varović držao je djeci školu. ${ }^{1} \mathrm{O}$ prvim početcima rada pučkih škola malo se zna u nas.

Ti prvi početci rada škola na našem senjskom području do danas su magličasti pa ih samo nagađamo i uspoređujemo s nekim sličnim podatcima iz davne prošlosti. Ako su se djeca u skupini, u grupi okupljala na jednom mjestu, $i$ ako ih je podučavao "ludi magister", onda se tu svakako mogu uzeti neki elementi prvih početaka pojave škola. Marko Pranjić u časopisu "Napredak", br. 3. iz godine 2015. navodi da još u 5. stoljeću prije Krista rimski povjesničar Tit Livije spominje dječačku školu u etrurskom gradu Faleriji. Isti autor u kasnijim svojim djelima spominje da je u nekoj daščri bila prva osnovna škola. Tu se radi o poučavanju djece u grupi, skupini koju su učili čitanju, pisanju i računanju. Prvi njihovi učitelji su se nazivali ludi magister. ${ }^{2}$ Navedeni podatak iz Izvješća župe u Sv. Jurju upućuje nas na sličan zaključak da je skupina djece okupljena na prostoru, ili oko svetojurske crkve, mnogo stoljeća kasnije (1733.) dobivala prve upute u pisanju, čitanju i računanju od mjesnog župnika. Nedvojbeno je da su to prvi početci poučavanja djece u grupi, ne u školi kao instituciji, već je to bio jedan oblik poučavanja djece na selu, u Hrvatskom primorju. I njihovi prvi učitelji su bili svećenici.

U senjskom Podgorju težak je život, pa je tako i život tamošnjih učitelja u prošlosti bio iznimno otežan. Bez ikakvih uvjeta stanovanja, bez elementarnih životnih potrepština i slabih plaća učitelji su se često odricali svojih radnih mjesta. Nakon stupanja na snagu Prvog hrvatskog školskog zakona 1874. (Mažuranićev zakon), pri gradnji novih školskih zgrada gradili su se i stanovi za učitelje u njima, ali to se nije događalo kod svake gradnje škole na području senjskog Podgorja. Primjerice, u Oltarima, odmah nakon otvaranja škole učiteljica je morala nakon nekoliko mjeseci napustiti mjesto jer nije imala stan. I u Lukovu je poslije Prvoga svjetskog rata učitelj bez stana. I on je morao samo nakon dva dana boravka napustiti mjesto. Slično je bilo stanje i u drugim mjestima gdje se nastava održavala u skučenim prostorima, najčešće po privatnim kućama.

Međutim, bilo je škola gdje su učitelji imali školske stanove, kao primjerice u Jablancu, Sv. Jurju, Bilopolju itd. U tim slučajevima primjenjivale su se zakonske odrednice.

Roditelji su nerado slali svoju djecu u školu, jer su im kod kuće obavljala svakodnevne kućanske poslove, čuvali stoku, pomagali u šumi i slično. Siromaštvo ih je tjeralo u "pitanje" i u pojedinim vremenskim razdobljima,

${ }^{1}$ J. BURIĆ, 2002, 77.

${ }^{2}$ M. PRANJIĆ, 2015, 169-203. 
prema broju štapa u kući procjenjivalo se njihovo bogatstvo. Premalo su imali novca za školske potrepštine. Preveliki je teret za roditelje bio slanje djece u škole kao i izvršavanje roditeljskih obveza prema njima.

Najčešće se nastava nije održavala redovito. Nepristupačni i teško prohodni seoski putovi, bura, kiša, snijeg i česte dječje bolesti otežavali su svakodnevni dolazak u škole kako djece tako i njihovih učitelja.

Dakako, sve ove spomenute činjenice valja promatrati u kontekstu vremena i školskih zakonskih odrednica. U mjestima gdje su radili mjesni župnici, kao učitelji, stanje u školama je bilo bolje jer su oni bili obrazovaniji i vještiji u nastavi (primjer škole u Lukovu).

Nakon Drugoga svjetskog rata u skladu s postojećim školskim zakonom rasla je potreba za otvaranjem viših razreda osnovne škole (školski zakon 1946. i školski zakon 1951.), ali prostor, oprema i učiteljski kadar bili su glavna zapreka tim nastojanjima. I zbog toga nekoliko godina kasnije (školske 1959/60.) prelaskom učenika u starije razrede u Jablanac i Sv. Juraj počinje postupno zatvaranje malih četverorazrednih osnovnih škola na području senjskog Podgorja.

\section{SENJSKO PODGORJE}

\section{Zemljopisno-povijesne i sociološke odrednice}

Razbacana sela i zaseoci u senjskom Podgorju danas djeluju više napuštena nego naseljena. Ne čuje se ni cika ni vika malodobne djece. Stanovnike senjskog Podgorja Senjani nazivaju Podgorcima. To je kraj južnije od Senja koji se prostire primorskim padinama planine Velebit. Krševito i na mnogim mjestima dosta nepristupačno područje ispresijecano je brojnim vododerinama i uskim kanjonima koji se pružaju od velebitskih vrhova sve do mora. Stanovnici su stoljećima ovdje živjeli od stočarstva, zemljoradnje i pomorstva. Oni uz more više su orijentirani na ribolov, trgovinu, a u novije vrijeme i turizam, koji sve više nalazi svoje mjesto baš u očuvanim oazama mira, čistoći mora i gostoljubivosti domaćih stanovnika.

Polovicom 17. stoljeća nastanjuju se prebjezi iz Dalmacije u područje današnjeg Podgorja. To su uglavnom pretci današnjeg podgorskog stanovništva ${ }^{3}$.

S formiranjem Vojne krajine ovo područje ulazi u njezin sastav, a u okviru otočke regimente. Stroge mjere koje su uvedene u Vojnoj krajini postupno mijenjaju način života u Podgorju. Vojnik i seljak u istoj osobi od 16. do 60. godine života bio je važan dio oružane austrijske sile prema turskim stranama. Unatoč jakoj vojnoj stezi i promijenjenom načinu života administrativnim ustrojem

\footnotetext{
${ }^{3}$ P. ROGIĆ, 1965, 44.
} 
Tab. 1. Broj stanovnika u podvelebitskim mjestima u razdoblju od 1948. do 2011. godine

\begin{tabular}{|l|r|r|r|r|r|r|}
\hline \multirow{2}{*}{ NASELJE } & \multicolumn{7}{|l|}{ GODINA POPISA STANOVNIŠTVA* } \\
\cline { 2 - 7 } & 1948 & 1971 & 1981 & 1991 & 2001 & \multicolumn{1}{l|}{2011} \\
\hline JABLANAC & 849 & 330 & 219 & 158 & 118 & 74 \\
\hline KLADA & 307 & 79 & 38 & 49 & 33 & 41 \\
\hline LUKOVO & 422 & 153 & 90 & 57 & 36 & 33 \\
\hline PRIZNA & 611 & 259 & 171 & 79 & 56 & 43 \\
\hline STARIGRAD & 264 & 74 & 54 & 29 & 11 & 15 \\
\hline SV. JURAJ & 559 & 745 & 686 & 691 & 692 & 604 \\
\hline V. BRISNICE & 155 & 23 & 4 & 1 & 1 & - \\
\hline
\end{tabular}

* Izvor podataka: Službeni popis stanovnika, Državni zavod za statistiku, Zagreb, 2003, 2011.

vojnih vlasti, ekonomske se prilike mijenjaju i nastojanjem pojedinih zapovjednih osoba (krajiških časnika) stvaraju se postupno donekle bolji uvjeti života. Tako se, primjerice, na području Jablanca, ali i šire izgrađuju kopneni putovi i povezuju okolna naselja s novoizgrađenim cestama, podižu se nove građevine za namještenike i državne službenike, ali i za potrebe drvene građe, koja se dovlačila iz velebitskih šuma. Zasađuju se nove biljne kulture, kao vinova loza, maslina i mendula. ${ }^{4}$ U vrijeme krajiške vlasti otvaraju se i pučke škole u Sv. Jurju i Jablancu. Godine 1830. Svetojurska kumpanija br. 12 broji 12 mjesta i 5319 stanovnika. ${ }^{5}$

Pripajanjem Vojne krajine civilnoj (građanskoj) Hrvatskoj (1871.) život u senjskom Podgorju nije se značajnije mijenjao. Stočarstvo, zemljoradnja i iskorištavanje šume bile su i ostale osnovne djelatnosti. Onaj dio stanovništva uz more bio je upućen na pomorstvo i ribolov. Od svega toga se teško živjelo. Stoga jedan dio Podgoraca odlazi u druge zemlje u potrazi za boljim životom. Pojačano iseljavanje Podgoraca vrši se između dva svjetska rata, a naročito poslije Drugoga svjetskog rata.. Tome su pridonijeli ponajviše onodobni lokalni politički moćnici bez jasne i konkretne gospodarske politike i bez težnje za napretkom ovoga osiromašenog Podvelebitja. Mlađi svijet odlazi nakon završene osnovne škole u obližnja gradska središta: Senj, Rijeku, Zagreb i drugdje, a jedan dio njih odlazi na privremeni rad u Slavoniju, odakle osiguravaju način preživljavanja svoje obitelji. U pojedinim školskim zapisima i sačuvanim ljetopisima zabilježeno je da se u oba svjetska rata, ali i prije i poslije njih, ponajviše u Podgorju prosilo te da je bogatstvo pojedinih obitelji ovisilo je o broju "štapa" u kući. Težak i oskudan život u prošlosti bio je temeljna odrednica Podgoraca.

${ }^{4}$ F. VANIČEK, 1875, 601-602.

${ }^{5}$ F. J. FRAS, 1835, 187-188. 


\section{ŠKOLE DO PRVOGA SVJETSKOGA RATA U SENJSKOM PODGORJU}

\section{Od trivijalne do četverorazredne pučke škole u Sv. Jurju}

Još je godine 1764. carica Marija Terezija naredila da se, prema vojnoteritorijalnom ustroju, u svakom štapskom mjestu i u svakom bataljunskom kotaru svake pukovnije (svaka krajiška pukovnija se sastojala od dva bataljuna a bataljun od šest krajiških satnija) mora ustrojiti najmanje po jedna njemačka škola na trošak države i uz pripomoć krajiških žitelja." Svaki podanik mora se naobraziti po svome zvanju i stališu tako, da istom odgovara. Učiteljska mjesta imadu se natječajem popunjavati, a učitelji moraju biti podpuno naobraženi za svoje zvanje...." ${ }^{6} \mathrm{~A}$ kada je 6. prosinca 1774. Felbigerovu reformu carica Marija Terezija prihvatila, u cijeloj austrijskoj državi počelo se raditi na otvaranju škola i to trivijalnih u svakom mjestu gdje je župna crkva, glavnih u svakom okružju, te normalnih škola u svakom sjedištu školske komisije ( sjedištu generalne komande). Ova administrativna naredba se dosljednije primjenjivala u Krajini.

Već godine 1775. u Sv. Jurju se otvara trivijalna škola s jednim učiteljem. ${ }^{7}$ U to doba cijelo je svetojursko područje imalo 2259 stanovnika pa je zbog velikoga broja djece postojala potreba za školom. ${ }^{8}$

Školska zgrada je bila podignuta na onome istom mjestu gdje je danas zgrada osnovne škole, ali je bila mnogo skromnija. Najprije se nastava držala u zgradi u kojoj je bila drvna agentura. Budući da se nalazila u razini zemlje morala je zbog snažnih "torrenta" (snažne bujice) odatle biti premještena. ${ }^{9} \mathrm{U}$ njoj su radila kasnije dva učitelja za mjesečnu plaću od 20, odnosno 15 forinti. Prema propisima školu su pohađali učenici od sedme godine života, a među njima je bilo djece različite dobi, čak i do 20 . godine.

U Vojnoj krajini su djeca, prema carskom naputku, školu polazila s navršenih šest godina života. I djevojčice su pohađale istu školu, ali su sjedile odvojeno od dječaka. Obuka se izvodila dvokratno, prije i poslije podne. Nastava je počinjala u 8 sati najprije $s$ računanjem, zatim se nastavljala $s$ učenjem poznavanja pisma i sricanjem, zatim čitanjem, učenjem pravopisa, vježbanjem u prepisivanju i u diktiranju. Svećenik je vjeronauk držao dva puta tjedno od 10 do 11 sati, $i$ to jedanput s manjom i drugi put s većom djecom..$^{10}$

\footnotetext{
${ }^{6}$ F. TIĆAK, $1880,7-8$.

${ }^{7}$ A. CUVAJ, 1910, 518; M. RAGUŽ, 1988, 215-224.

${ }^{8}$ Schematismus cleri Segnicusis et Modrušiensis seu Corbaviensis Segniae, 1905, 50.

${ }^{9} \mathrm{~F}$. BACH, 1855, 321.

${ }^{10}$ A. CUVAJ, 1910, 425.
} 
Na temelju skromnih školskih podataka zna se da su u to prvotno doba radile i opetovnice, obvezno nedjeljom i blagdanom. Opetovnica je bila obvezna za one učenike koji se nisu namjeravali dalje školovati. Mnoga su djeca ostajala bez ikakve naobrazbe. Godine 1792. škola je prestala s radom, ukinuta je. Do prekida je došlo zbog naleta vodene bujice koja je zgradu uništila. Škola je ponovno otvorena godine 1799. Pretpostavljam da je do prekida moglo doći i zbog nedostatka učitelja, jer je u to vrijeme manjak učitelja bila stalna pojava. S ovoga spomenutoga dosadašnjeg mjesta škola je premještena "uvrh sela" godine 1843. U toj školi se nastava drži sve do godine 1960. Tko je bio prvi učitelj u ovoj školi, nije nam poznato. Tek polovicom 19. stoljeća F. Bach nam u svojoj knjizi Otočaner regiments-geschichte spominje imena nekoliko učitelja koji su radili od godine 1828 .

Tako on navodi da su od godine 1828. do 1844. radili u toj školi Josip Vuković, Josip Juršić, Petar Luger i Petar Fabiani. Godine 1845. radio je učitelj Pinter. Ime mu ne navodi. Od godine 1846. do 1849. radi Kramarić. Godine 1850. spominje se učitelj Stanislav Milaković, a nakon njega učitelj Stjepan Luketić koji je radio nekoliko godina. ${ }^{11}$

Prema jednom podatku onodobnog mjesnog katehete u Bikupskom ordinarijatu u Senju, godine 1870. stoji da je katoličke školske mladeži u Sv. Jurju bilo u početnom razredu 19, u prvom razredu 9, drugom 11 i trećem 4 polaznika. Već sljedeće školske godine, 1870./71. u početnom ih je 17, prvom 12, drugom 8 i trećem razredu 9 polaznika. Njihov vjeroučitelj je tada bio Ambroz Krišković, teolog koji je završio Visoku teološku školu u Senju. ${ }^{12}$

U Sv. Jurju djelovale su dvije škole: jedna carsko-kraljevska trivijalna njemačka, podignuta 1799., a u njoj je učitelj Josip Juršić iz Ogulina, a druga osnovna pučka podignuta je 1. travnja 1836. Učitelj u njoj je Karlo Biondić, mještanin Sv. Jurja. Upravitelj jedne i druge škole je Julije Fras koji boravi u Karlovcu. Jedna i druga škola pripadaju generalnoj ispostavi u Karlovcu. ${ }^{13}$ Jesu li djelovale dvije škole ? Ovaj se podatak nalazi samo u Biskupskom arhivu u Senju. Ne spominje ga Bach, a ni Cuvaj, ni Fras. Gdje se nalazila ta druga škola u području svetojurske župe - nije poznato.

Nažalost, nisu nam poznati učitelji koji su kasnije radili u toj školi. Tek godine 1911. u sačuvanim školskim dokumentima stoji da su u školi radili Nikola Dujmović i Mileva Prpić. Pretpostavljamo da su oni ranije došli u

\footnotetext{
${ }^{11} \mathrm{~F}$. BACH, 1855, 321.

${ }^{12}$ BAS, Spisi, Sv. Juraj, 1870.

${ }^{13}$ BAS, 1836.
} 
ovu školu. U Sv. Juraj došao je kao učiteljski pripravnik Mate Majer godine 1907. ${ }^{14}$ Zbog svoga dugogodišnjega rada i učiteljskoga djelovanja Majer je u ovome kraju ostavio dubok pečat, posebice u vrijeme vršenja nadzorničke dužnosti. Dugi niz godina s njim su radili Marija Sabljak i Božidar Abramić. Uz nastavu je Majer obavljao niz drugih dužnosti u mjestu i općini. Tako stoji u jednom zapisu da je ovaj učitelj bio predsjednik kotarskog društva učitelja za kotare Senj i Brinje i da ih je 1934. godine zastupao na izvanrednoj skupštini Jugoslavenskog učiteljskog udruženja, koja se održala 4. ožujka 1934. u Beogradu.

Od "Allgemeine Schulordnunga" koji je donesen godine 1774. pa sve do prvoga autonomnoga hrvatskoga školskog zakona 1874. godine nadzor nad školama je vršila Crkva. U Vojnoj krajini je bilo drukčije. Dvorsko ratno vijeće izdalo je 8. siječnja 1780. " Instrukcije za vizitatore pukovnijskih i komunitetskih škola u Vojnoj krajini. Prema njima nadzor nad trivijalnim školama vršili su nadučitelji (Oberlehrer ).

Postavljene su i satnijske komisije koje su brinule o područnim školama. Službu nadglednika su vršili satnici u svojoj satniji. U početku je nadzor vršio mjesni župnik, ako je poznavao njemački jezik, a ako nije, onda je tu zadaću obavljao zapovjednik kompanije. ${ }^{15}$

\section{ŠKOLA U SV. JURJU IZMEĐU DVA SVJETSKA RATA}

Nastava se nije prekidala u vrijeme Prvoga svjetskoga rata, ali dolazak djece iz okolnih sela Planikovca, Duboke, Žrnovnice i Smokvice bio je i te kako otežan baš u tim ratnim prilikama.

U školskom izvješću iz godine 1931./32. stoji da je škola u Sv. Jurju raspolagala sa 157 knjiga za nastavnike, a za đake sa 677 primjeraka. U istom izvješću stoji da je te godine bio u prvome razredu 21 đak, u drugom ih je bilo 17, trećem 23, četvrtom 11, petom 6 i u šestome razredu 3 učenika. Ukupno je te godine pohađalo nastavu 81 učenik. Dakle, te školske godine je u Sv. Jurju

${ }^{14}$ Mate Majer (1885.-1950.) je rodom iz Švice u Lici. Nakon završetka učiteljske škole privremeno je imenovan 12. travnja 1907. godine učiteljem u Sv. Jurju. Prisegu je položio 6. svibnja iste godine, a definitivno imenovan za učitelja godine 1910. Tako počinje dugo učiteljevanje ovoga vrsnoga prosvjetnog djelatnika koje je trajalo sve do umirovljenja. Jedno je vrijeme radio kao školski nadzornik, a samo nakratko kao učitelj u Krasnu, Oltarima i Sušnju kraj Karlobaga. Mještani o njemu govore s poštovanjem, a njegovi ga učenici pamte kao stroga, ali vrlo pravednoga učitelja.

${ }^{15}$ A. CUVAJ, 1910, 510-518. 
djelovala šestorazredna osnovna škola, što je bilo u skladu s važećim školskim zakonom. To nije uvijek bilo tako. Kasnije u školskim izvješćima ne nalazimo podatke o broju polaznika u petim i šestim razredima. Da su Marija Sabljak i Mate Majer bili vrlo strogi učitelji, govori i podatak da je te školske godine na kraju upućeno na ponavljanje razreda 13 učenika. S odličnom ocjenom su ocijenjena samo dva učenika, vrlo dobrih je bilo devet učenika, a dobrih pedeset i šest učenika.

Prema statističkom izvješću između dva svjetska rata školu su polazili učenici iz Sv. Jurja, Planikovca, Zakose, Hrmotina, Burnjaka, Donje Smokvice i Žrnovnice. Uz školu je bio školski vrt od 1400 četvornih metara.

Između dva rata ova je škola nosila naziv Državna narodna škola Sv. Juraj. Školske godine 1935./36. prvi i drugi razred s 40 učenika vodio je Božidar Abramić, a treći i četvrti razred sa 38 učenika upravitelj škole Mate Majer. Ne spominje se peti i šesti razred. Te školske godine je radila i školska kuhinja u kojoj se hranilo 65 učenika.

U zapisniku Nastavničkog vijeća od 20. lipnja 1936. stoji da je Abramić ocijenjen s vrlo dobrim, a njegov ravnatelj Majer s odličnom ocjenom.

Te ocjene su dobili od svoga kotarskog školskog nadzornika. I te kako se vodila briga o kvaliteti rada učitelja. U proračunu su za nastavnu godinu 1938./39. dobili 12900 dinara, od čega je 28 posto otpadalo na učiteljske stanarine. Učitelji su dobivali još i 16 kubičnih metara ogrjevnih drva, a neoženjeni samo 8 metara. Iz jednog drugoga zapisnika Nastavničkog vijeća (29.10.1936.) zanimljivo je spomenuti da se za održavanje školskog vrta tražilo 2500 dinara, a za nabavu i održavanje školskih učila samo 1000 dinara. Pomoć za nabavu udžbenika za siromašnu djecu iznosila je 2500 dinara.

Između dva rata radile su još Vilma Ostović i Ružica Fiorentin. Školske godine 1938./39. Vilma Ostović je vodila prvi i drugi razred s 45 učenika.

Učitelj Majer odlazi u mirovinu 23. studenoga 1940. Učiteljica Fiorentin je školske godine 1940./41. kao početnica od kotarskog školskoga nadzornika Nikole Šimunića ocijenjena kao vrlo uspješna učiteljica. Ona je krajem godine 1940. došla na školu i radila sama sa sva četiri razreda. Kada je ona otišla, na njezino mjesto dolazi 25. studenoga 1941. Josipa Babić.

I u vrijeme Drugoga svjetskog rata škola nije prekidala s radom. U tim najtežim ratnim godinama u školi su radili Ljudevit Fuks, Dragica Vukelić i Josipa Babić. 


\section{PREMA OSMORAZREDNOJ SREDIŠNJOJ OSNOVNOJ ŠKOLI USV. JURJU}

Nakon Drugoga svjetskoga rata prvi na dužnost u školu su se javili umirovljeni učitelj Mate Majer i Marica Moćan. Do učitelja se teško dolazilo. U izvješću Državne narodne škole Sveti Juraj Prosvjetnom odjelu kotarskoga narodnooslobodilačkoga odbora u Senju br. 1 od 24. svibnja 1945. stoji da su spomenuti učitelji stupili na dužnost i počeli s radom. U srpnju iste godine pri ovoj školi formiran je prosvjetni aktiv od 9 članova. U nj su ušli Krsto Vukelić, pročelnik prosvjetnog odjela, Mate Majer, učitelj ( upravitelj škole), Ivan Rogić, član narodnooslobodilačkog odbora (NOO), Đura Gulišija i Katica Stojan, predstavnice antifašističkog fronta žena (AFŽ-a), Ana Popović, predstavnica Ujedinjenog saveza antifašističke omladine Hrvatske (USAOH-a), Joso Rukavina, Mila Lukanović i Lovre Skorup kao članovi, predstavnici roditelja. Ovaj prosvjetni aktiv imao je zadaću upravljanja prosvjetnim radom i da pazi da se odgojno-obrazovni rad izvodi u duhu narodnooslobodilačkog pokreta. ${ }^{16}$ Te prve godine nakon završetka Drugog svjetskog rata upisano je 55 učenika u sva četiri razreda.

Ratna pustošenja nisu poštedjela ni škole. Svetojursku školu, onu "uvrh sela", skupa s inventarom uništila je njemačka vojska koja se tijekom čitave 1944. godine nalazila u njoj. Prema dopisu pod brojem 576/45, Prosvjetnom odjelu u Senju na njihov upit iz škole su poslani podatci da je škola imala zbornicu, dvije učionice i sporedne prostorije s vanjskim prostorom od 1400 četvornih metara. Za vrijeme boravka njemačkih vojnika uništeni su svi prozori, sva vrata i cjelokupna fasada na zgradi. Uništena je knjižnica i sva školska učila. Ukupni iznos štete je procijenjen na 110000 predratnih dinara. Pri školi nije bilo učiteljskog stana. Stoga se u tim prvim poratnim danima radilo na tome da se osiguraju osnovni uvjeti za rad. Uz redovitu nastavu organizirana je tečajna nastava za djecu od 9 do 14 godina života koja u tijeku rata nisu pohađala školu. Također su odmah organizirani i analfabetski tečajevi za nepismene osobe starije od 14 godina. Te poratne godine su bile opterećene brojnim teškoćama među kojima i pomanjkanjem prosvjetnoga kadra. Mnogo je djece trebalo pohađati školu, tražilo se od roditelja da svi šalju svoju djecu u školu. Izašao je Zakon o sedmogodišnjem obvezatnom općem obrazovanju 30. kolovoza 1946. godine, a 1950. Zakon o obvezatnom osmogodišnjem obrazovanju. Ova je škola odmah željela primjenjivati važeće zakonske propise.

\footnotetext{
${ }^{16}$ Ovi podatci nalaze se u Školskoj spomenici Osnovne škole Sv. Juraj.
} 
Tako se školske 1946./47. osniva peti, a sljedeće školske godine i šesti razred. Budući da je bilo malo učitelja, postupno se uvodi prijelazni tip šestogodišnje škole (4+2). Učitelji su se malo zadržavali na školi, slabo vodili brigu o cjelokupnom obrazovnom stanju i tražili povoljnije radne i životne mogućnosti negdje drugdje. Kada je ovu školu posjetio školski inspektor Ministarstva i prosvjete Drago Juraković (18.2.1949. g.), nije bio zadovoljan postojećim stanjem u školi. Učitelji su se premalo zalagali u radu, a pripremanje za nastavu nisu vodili gotovo nikako. S obzirom na sveukupno stanje u odgoju i osnovnom obrazovanju, to nije bilo neobično. U tom poslijeratnom vremenu broj polaznika je bio približno podjednak. Zanimljivo je i to da su roditelji malo brinuli o odgojnim problemima svoje djece. Polazak je bio neredovit, uslijed čega nastaju brojni problemi obrazovne naravi. A bilo je teškoća oko polaska učenika u starije razrede. Roditelji su djecu nerado slali u školu ostavljajući ih radije kod kuće da obavljaju svakodnevne poslove oko svojih domova.

Školske godine 1954./55. na području senjskog Podgorja djelovale su kao šestogodišnje škole: Dundović Pod, Brisnice, Dušikrava, Jablanac Lukovo, Oltari, Prizna i Sv. Juraj, a kao četverogodišnje škole: Bilopolje, Gornji Starigrad i Vlaka. U to vrijeme svaka je škola bila samostalna. Neposredno su njima upravljali mjesni učitelji, odgovorni mjerodavnim općinskim i kotarskim školskim vlastima.

Godine 1953. počinje prva reforma obrazovnog sustava u Hrvatskoj kojom se uspostavlja jedinstvena obvezatna osnovna škola u trajanju od osam godina. Tu odluku je teško bilo provesti u svim dijelovima Hrvatske. Temeljni problemi su kadar i prostor. Oba ova uvjeta su se vrlo teško ostvarivala u to vrijeme. Male seoske škole su bile jednostavne zgrade s malim učioničkim prostorom, najčešće $\mathrm{s}$ jednom sobom i pratećim prostorijama, što je nedovoljno za nastavu s više razreda. Tako, primjerice, u Sv. Jurju školske 1953./54. djeluje šestorazredna škola s četiri odjela u kombinacijama prvi i peti razred, te četvrti i šesti razred, dok su treći i drugi razred bili čisti odjeli. S njima su radile samo dvije učiteljice u dvije vrlo trošne učionice.

Većina škola na senjskom području prerastaju u osmorazredne škole pa tako i ova u Jurjevu. Stručnoga kadra i dalje nedostaje, osobito za starije razrede, pa se veliki broj učitelja upućivao na doškolovanje (izvanrednim dvogodišnjim studijem na pedagoškim akademijama).

Postupno se stvaraju jači školski centri od kojih su se na podgorskom području razvile dvije osmorazredne škole, i to Jurjevo i Jablanac. Ostale škole, kao četverorazredne, u svojim mjestima ostaju sve dok ima djece. Ali nažalost, one se postupno gase nešto utjecajem političke moći, a nešto i pomanjkanjem djece. 


\section{PUČKA ŠKOLA U JABLANCU}

Danas Jablanac s okolicom ima malo žitelja. Prema popisu iz godine 1991. broj stanovnika Jablanca iznosio je 158. Mjesto ima crkvu, poštu i trgovinu, danas je bez djece, bez škole i bez razvojnih planova za budućnost. Hoće li se nešto promijeniti u svemu tome, ne zna se.

Tijekom minulih stoljeća na ovome prostoru živjelo je daleko više ljudi. U jednom popisu tamošnjeg župnika iz 1734. područje Jablanca brojilo je 2592 stanovnika. ${ }^{17}$ Uže područje Jablanca 1857. godine broji 986 stanovnika. Uspostavom Vojne krajine i ovo područje potpada pod upravu Otočke pukovnije, koja se nalazi u sastavu Karlovačkog generalata.

Radi upoznavanja svoje zemlje car Josip II, prolazeći Primorjem, posjetio je 11. svibnja 1775. Jablanac, Sv. Juraj i Senj, nakon toga je ojačao interes mjerodavnih krajiških vlasti za ovo područje. Tako već 21 . siječnja 1780 . godine Generalna komanda Vojne krajine zapovijeda između ostaloga da se izda dozvola za gradnju škole u Jablancu, što je već 16. svibnja iste godine i učinjeno ${ }^{18}$.

Djece je bilo mnogo, a mjesto bez škole. Samo je u to doba djelovala jedna erarska škola u Sv. Jurju. Iako je odmah učinjeno mnogo oko početka gradnje škole u Jablancu, zbog mjesnih nesuglasica oko toga gdje će se graditi školska zgrada svi poslovi na tome su za punih pedeset godina odgođeni. Nesuglasice su najžešće bile vezane uz pitanje na kojoj će se čestici graditi sama zgrada. U Ljetopisu ove škole stoji da su radovi počeli 1830., a dovršeni 1832. Međutim, F. Bach godine 1835. piše u svojoj knjizi "Otočaner Regiments-Geschichte" da je u Jablancu odobrena gradnja škole 1780., ali je sagrađena tek 1825. Škola je izgrađena u Dragi, a kada je bila gotova, tamošnji župnik Mihovil Martinčić preseljava se u nju. Ovaj župnik je bio senjski sjemeništarac i student Teološkog učilišta u Senju od 1816. do 1819. Ne znamo je li on bio prvim učiteljem u njoj, ali završeni senjski teolozi su u nekim senjskim školama u to doba vršili učiteljske službe i držali vjeronauk u školama.

Posve je sigurno da je to bila u početku trivijalna škola s njemačkim nastavnim jezikom. ${ }^{19}$ Nakon sedam godina, 1832. škola se preseljava u Sinac u

${ }^{17}$ Schematsmus cleri Segniensis et Modrušiensis seu Corbaviensis, Segniae, 1905, 52-53.

${ }^{18}$ A. CUVAJ, 1910, 519.

19 Trivijalna škola - početni stupanj latinske škole u srednjem vijeku. Na tom stupnju izučavao se samo trivij. U 18 st. nazivao se trivijalnom školom najniži tip škole za narod, kakav je bio, primjerice, uveden Felbingerovom školskom reformom u Austriji. U tim školama poučavao je samo jedan učitelj, a imale su dva razreda. Osnivali su ih u manjim mjestima. Takva škola je u početku bila i u Jablancu. F. J. FRAS, 1835, 257-258; M. RAGUŽ, 1993, 195-200. 
Lici. To preseljavanje je povezano s pomanjkanjem učitelja. Jer, nikako se nije mogla preseliti škola, već samo otići učitelj u Sinac, a djeca i zgrada su ostali u mjestu. Učitelji su najčešće u to vrijeme bili vojni časnici, pa se to preseljavanje često događalo u Vojnoj krajini.

Franjo Julije Fras, upravitelj krajiških škola, tvrdi da je godine 1829. u Jablancu ustanovljena erarska škola, koja je zatim godine 1832. preseljena u Sinac. ${ }^{20}$ Iza preseljenja škola nije radila sve do 1848., pa je u njoj stanovao mjesni župnik.

Škola je u početku djelovala kao cesarsko-kraljevska trivijalna škola. U njoj su kao i u svim drugim trivijalnim školama vladala stroga pravila ponašanja. Uglavnom se učilo čitati, pisati i računati. Valja spomenuti da su za ondašnje doba trivijalni učitelji bili vrlo obrazovani, ali kao stranci malo su mogli utjecati na značajnije promjene u mjestu. S vremenom se mijenjaju učitelji, pa i sama organizacija nastave u tim trivijalkama. Umjesto talijanskog, odnosno njemačkoga jezika, postupno ulazi u škole hrvatski duh, jezik i nastava postaju sve razumljiviji i pristupačniji hrvatskoj mladeži, koja pučku školu doživljava kao svoju potrebu.

Godine 1871. prestaje vojna uprava u ovome kraju, ali i dalje Jablanac ostaje pod upravom Ličko-krbavske županije, čije je školsko središte u Gospiću. Brojni službeni spisi i školska izvješća odlaze u Gospić. I školski nadzornici obvezatno su slali svoje zapisnike i mišljenja o djelovanju učitelja u školi. Među prvim učiteljima spominje se Božo Duić.

U školskom ljetopisu stoji da je prvi narodni učitelj bio Joso Butorac. U pregledu postojećih erarskih škola i njihovih učitelja F. Bach spominje Božu Duića, što bi svakako više odgovaralo jer je on bio njegov suvremenik.

S dolaskom Jose Butorca za učitelja škola u Jablancu dobiva službeni naziv pučka učionica. Za razliku od njegovih prethodnika, ovog učitelja mještani cijene pa uz pomoć djece i roditelja uređuje školsko igralište i vrt. ${ }^{21}$ Oko škole zasađuje dud i masline. S njim je radila i učiteljica Jelka Miškulin. Posebno je ostala u sjećanju mještanima što je djevojčice učila ručnom radu. Dakako, to je bilo u skladu sa školskim propisima i propisanim nastavnim programima za niže pučke škole. Razvijala je kod ženske mladeži kulturu obiteljskog života. Godine 1892. u školi radi kao učitelj Fabe Orešković. On je dosta radio na oplemenjivanju školskog okoliša ukrasnim biljem i s djecom je radio na uzgoju

${ }^{20}$ F. J. FRAS, 1835, 257-258; M. RAGUŽ, 1993, 195-200.

${ }^{21}$ Školski vrt u Jablancu bio je uzoran, stoji u Ljetopisu ove škole. 
dudova svilca. Poslije se u ovoj školi učitelji izmjenjuju vrlo često, što se može pregledno utvrditi u Imeniku učenika. ${ }^{22}$

U vremenu od godine 1893. do 1897. radili su učitelji Ivan Matijević, Ljudevit Luketić, Juraj Murgić, Ivka Medveščak, Milan Prpić i Gustav Šrajber. Ovaj potonji radi od godine 1897. do 1906. pa se spominje i u školskom Ljetopisu i drugim dokumentima kao strastven lovac, zbog čega je jednoga dana i nastradao. Za njegova učiteljevanja, po odluci Školskog odbora od 28. veljače 1899., ukinuta je opetovnica u Jablancu.

U spomenutom Imeniku učenika od 1892. svake školske godine upisivan je prvi razred u kojem se nalazi najčešće između 22 i 26 učenika. Do početka Prvoga svjetskoga rata nema sačuvanih drugih školskih dokumenata u kojima bismo našli nešto više o tome. A kako je obično u tome razdoblju djelovao po jedan učitelj, može se pretpostaviti da je u Jablancu nastava držana prije i poslije podne, te da je učitelj imao i preko stotinu učenika u sva četiri razreda. Analizirajući podatke u spomenutome Imeniku, zaključujem da su pojedini učenici ponavljali pojedine razrede i po nekoliko puta.

\section{ŠKOLA U JABLANCU IZMEĐU DVA RATA}

Uoči Prvoga svjetskog rata ovdje su radili Matilda Bašić, Franjka Butković i Božena Rivoseki. U to vrijeme vladala je u Podgorju velika glad i neimaština. Zbog otežanih životnih prilika teško je bilo držati nastavu u Jablancu. Učiteljice su se teško snalazile, a najčešće su gladovale. I kao što su žitelji Lukova većinom prosjačili, jednako tako su i Jablančani dolazili do hrane. Posebno je to značajno za razdoblje između 1911. i 1918. godine, kada je u Jablancu radila učiteljica Hedviga Radović. Da bi nekako privukla djecu u školu, otvorila je školsku kuhinju, u kojoj je za svu djecu osigurala topli obrok. Nažalost to nije dugo trajalo. Kada je Hedviga napustila Jablanac, na njezino mjesto došao je učitelj Mijo Kostelac iz Švice, a poslije njega Mato Ribarić, koji je prije toga punih dvanaest godina radio u školi u Prizni. Kada je još godine 1908. otvorena škola u Prizni, veliki broj djece okolnih zaselaka odlazi iz jablanačke škole u Priznu. Tako se smanjuje broj djece, pa se može pretpostaviti da su od tada tamošnji učitelji lakše radili.

Nakon završetka Prvoga svjetskog rata mijenjaju se učitelji, ali teškoće ostaju ovdje gotovo uvijek iste: neredovito pohađanje nastave, siromaštvo, oskudice i sve drugo utječu na učenje i znanje učenika, ali i duljinu učiteljevanja pojedinih

\footnotetext{
${ }^{22}$ Imenik učenika Pučke škole Jablanac od 1892. do...( nema bilješke).
} 
prosvjetnih djelatnika. To je vrijeme kada se ozbiljnije razmišlja o gradnji nove škole. Tako već 1935. mještani grade novu školsku zgradu na Brižini (današnja zgrada pučke škole, zatvorena je, bez đaka, a zgradu je otkupio privatni obrtnik).

U prizemlju su izgrađene tri velike učionice, svaka s oko šezdesetak četvornih metara korisnog prostora, a na katu se nalazio učiteljski stan s dvije sobe i kuhinja. Cijela školska zgrada se doimala kao jedan prekrasan dvorac, koji i danas dominira cjelokupnim jablanačkim prostorom. Škola je raspolagala velikim školskim okolišem. Nakon izgradnje u njoj su radili bračni par Labaj (Ivan i Barica), koji dosta napora ulažu oko uljepšavanja školskog okoliša, koji je i danas dijelom ukras ove škole. Za vrijeme Drugoga svjetskog rata škola radi povremeno. Prekidi su nastajali zbog ratnih okolnosti, pomanjkanje učitelja i straha roditelja koji su se bojali kad bi djeca odlazila od kuće.

\section{PUČKA Г̌KOLA U LUKOVU OTOČKOM}

Rad škole od osnivanja do Prvog svjetskog rata

Na početku 19. stoljeća prema jednom popisu Lukovo je imalo 842 stanovnika. ${ }^{23}$ Čitav je kraj dosta kamenit i neprohodan. Malo je obradivog zemljišta, pa su stanovnici Podgorja većinom živjeli od mora, stočarstva i, u određenim vremenskim razdobljima, od prošnje. Kuća s najviše "štapa" imala je više izgleda za preživljavanje. U župnom ljetopisu je mjesni župnik zapisao na kraju 19. stoljeća da je cijeli taj kraj živio od "pitanja", tj. od prošnje. On kaže da su Podgorci, Svetojurački i Jablanački, kasnije taj zanat zamijenili "sljeparijom i varanjem". Mjesni župnik i učitelj Vencel Potočnjak ovako počinje opis samoga mjesta Lukovo: " Lukovo se nanizalo u dolini, ispod gordog Velebita koji s jugoistoka zakriljuje strma Grivinjača, a sa sjeveroistoka položita Piskulja. Sredinom te doline prolazi sada vododerina. Ali do godine 1849. bijahu tuda bujni vinogradi, koje je iste godine (19. X.) prva bujica odnijela u more. Još je ta bujica i ine štete nanijela, jer osim što propadoše vinogradi, voda je odnijela par stotina koza i ovaca, a ugrabila je i jedan ljudski život (Pave Rogić, otac Pilandrin ) srušivši i kuću br. 35 pokraj sadašnje Prcanove kuće." 24

Zbog velikog broja djece, 15. siječnja 1894. u Lukovu Otočkom utemeljena je osnovna škola ${ }^{25}$ u nazočnosti izaslanika Kraljevsko-kotarske oblasti u Senju,

\footnotetext{
${ }^{23}$ Schematismus cleri dioecesium Segniensis et odrušiensis seu Corbaviensis, Segniae, 1905.

${ }^{24}$ Spomenica župe Lukovo, 11-12. U Školskom ljetopisu Pučke škole Lukovo zapisano je da je 15. siječnja 1894. otvorena škola sa 28 polaznika. M. RAGUŽ, 1990, 291-300.

${ }^{25}$ U Školskom ljetopisu Pučke škole Lukoovo zapisano je da je 15. siječnja 1894. otvorena škola sa 28 polaznika. M. RAGUŽ, 1990, 291-300.
} 
gospodina Hamela i Općinskog načelnika gospodina Lukanovića, o čijem se razvoju brinuo i tadašnji predstojnik Odjela za bogoštovlje i nastavu dr. Izidor Kršnjavi. Te prve godine školu je pohađalo 28 učenika, a broj obveznika je bio 132. Djeca su dolazila u školu iz naselja: Biluća, Doline, Tomaić Drage, Dragičević Doca, Gornje Klade, Panosa, Rastovca, Selina, Struge, Trnovca, Zagona pa i šire. Prvi učitelj u Lukovu je bio upravitelj župe Anton Polessi. U spomenutom župnom ljetopisu samo na dva mjesta se spominje škola. " Godine 1894. otvorio je Polessi pučku školu u Lukovu"26 i " Ono malo djece što polazi školu, sva su otvorena, bistra i nadarena, pa lahko shvaćaju i pamte. Dobra su. Da školu i crkvu pomaže i roditeljski dom uspjeh bi bio zamjeran i divan. ${ }^{27}$. Ove misli je zapisao don Dragutin Hlača u župnom Ljetopisu.

Iako to nisu bili početci rada na opismenjivanju djece toga kraja u širem smislu, jer su i do tada neka djeca imućnijih roditelja išla u školu u Sv. Jurju, školstvu se pridavalo dužno poštovanje. Mjerodavne školske vlasti redovito su kontrolirale i obilazile školu. Nadzorne školske službe provode instruktivnosavjetodavnu funkciju i nastoje unijeti suvremeni duh u nastavu. Školu su u Lukovu posjećivali i najveći crkveni i školski predstavnici. Tako se spominju dr. Izidor Kršnjavi, predstojnik Odjela za bogoštovlje i nastavu, u pratnji velikog župana Bude Budisavljevića koji su 28. kolovoza te iste godine razgovarali s djecom u školi. A kako je i te godine škola bila smještena u jednom privatnom stanu, dr. Kršnjavi je, držeći potrebnim da se gradi nova školska zgrada, obećao pomoć od 1000 forinti kao i još 1000 forinti pomoći općini iz zemaljskih sredstava za gradnju nove školske zgrade. ${ }^{28}$ Kasnije, nigdje u ovim školskim dokumentima ne nalazimo podatak kada je školska zgrada izgrađena, ali je sasvim sigurno da je ona podignuta prije Prvoga svjetskog rata. Odmah te godine je Kraljevskozemaljska vlada platila unutarnje uređenje škole. U Ljetopisu nema zabilježeno koliko su ta sredstva iznosila, već samo to da su se donekle uredili školski prostori.

Dvije godine kasnije Polessi odlazi u Kostrenu, a umjesto njega dolazi Vencel Potočnjak, koji preuzima dužnost učitelja za mjesečnu plaću u iznosu od 16 forinti i 66 novčića. Te je godine školu pohađalo 32 učenika, i to samo muška djeca, jer kako navodi tamošnji učitelj u školskoj Spomenici da se zbog

${ }^{26}$ Ljetopis župe Lukovo, 46.

${ }^{27}$ Ljetopis župe Lukovo, 71.

${ }^{28}$ Spomenica škole Lukovo, 1. Sredstva koja je obećao dr. I. Kršnjavi pri prvoj posjeti školi u Lukovu, odobrila je u rujnu 1894. godine Viša zemaljska vlada za unutarnje uređenje prostorije u kojoj se držala nastava. Čim je dr. Kršnjavi dao prijedlog za gradnju škole, A. Maurović, biskup senjski i modruški, dopustio je da se na župnoj parceli br. 5202 slobodno gradi škola, tako stoji u Ljetopisu Pučke škole u Lukovu. 
malih i slabih školskih prostorija " niesu se mogle do sada uškolati djevojčice". I dalje se nastava održava u kući pomorca Mile Rogića, bez ikakvih didaktičkih sredstava i pomagala. Mjesni školski nadzornik bio je cestar Anton Adžić, obrazovan za onodobne prilike i vrlo vrijedan čovjek. Članovi Školskog odbora bili su: Mate Adžić, Vicko Babić i Vicko Rogić, bez osobitih kompetencija. Na sjednici Školskog odbora održanoj 24. svibnja 1894. mjesni školski nadzornik Anton Adžić predlaže da županijska oblast zaključi školsku godinu 19. srpnja jer da u to vrijeme ovdašnje pučanstvo "odseljuje u planinu, stoga moraju i djeca". Da se ovaj Školski odbor bavio i drugim pitanjima, govori podatak zabilježen 19. travnja 1896. godine koji kaže i traži da se nabave sve potrebne školske stvari. "Budući da je i do sada ovu školu u svih potrepštinah i naviek na vrieme opskrbivala senjska knjižara T. Devčić com. U Senju, stoga mnije da bi se toj prokušanoj firmi povjerila dobava svega, što je školi potrebno". ${ }^{29}$

Isto su se tako brinuli o redovnom pohađanju škole pa su preko mjesnog župnika Vencela Potočnjaka opominjali roditelje da redovito šalju djecu u školu.

Za predsjednika školskog odbora izabran je Mate Adžić (9. kolovoza 1896.) jer je on jedini u odboru uz mjesnog školskog nadzornika koji zna čitati i pisati, a uz to je i starješina. Tih prvih godina svoga rada Vencel Potočnjak je imao dobrih rezultata u radu s djecom, što je pokazao prvi javni ispit održan 11. srpnja godine 1896. pred dr. Kršnjavim, roditeljima i ostalim mještanima u Lukovu. Prvi razred završilo je 8 učenika s ocjenom prvi red, 4 s odlikom, dok ih je 8 upućeno na ponavljanje razreda. Drugi razred imao je 12 učenika od kojih je 9 završilo s prvim redom, a 3 učenika s odlikom. Školu je redovito posjećivao i kraljevsko-županijski školski nadzornik. Godine 1896. zabilježeno je u službenom dopisu da župnik mora držati nastavu i preko ljeta, i to do sedam sati ujutro jer kasnije su djeca zauzeta čuvanjem stoke. Ovakva odredba je išla na ruku roditeljima čija su djeca imala važna zaduženja u kući. Prilikom jedne posjete nadzornika iste godine od ukupno 29 učenika sakupljeno ih je jedva 9. Iz razgovora s tom djecom, zaključio je nadzornik da nisu baš mnogo naučila, ali kako tadašnji učitelj pokazuje "dobru volju i lijep način u obucu", moglo se očekivati da će djeca bez zaostataka s uspjehom i na vrijeme sve propušteno otkloniti. ${ }^{30}$ To se i pokazalo na završnom ispitu na kraju školske godine.

\footnotetext{
${ }^{29}$ U knjizi zapisnika Školskog odbora od 19. travnja 1896. ima niz podataka o radu Školskog odbora ove škole i brizi za polazak školske djece.

${ }^{30}$ Kontrolna knjiga škole u Lukovu raspolaže s dosta podataka o posjetama školskih nadzornika ovoj školi, među kojima je i ova spomenuta.
} 
Školske 1896./97. upisana su 34 učenika, među kojima se prvi put spominju dvije djevojčice. Te se godine spominje da je škola raspolagala s nekoliko knjiga i da su u posudbi imali zemljaricu Hrvatske, Slavonije i Dalmacije. Škola u Sv. Jurju darovala je u ožujku 1897. školi u Lukovu zemljovid Hrvatske.

Godine 1897. za školu su na popisu bila 172 obveznika, a upisano ih je samo 35. To je bio otprilike kapacitet prostorije u kojoj se obuka održavala, jer se ni kasnije ne spominje veći broj djece koja redovito pohađaju nastavu. Među ovim novoupisanim učenicima nalazile su se i dvije djevojčice, i to jedna u trećem i jedna u drugom razredu. Te godine, 11. srpnja Općinsko poglavarstvo u Sv. Jurju uputilo je u školu u Lukovu dopis br. 1689 kojim izvješćuje Visokozemaljska vlada " da se za sada odustaje na prijedlog općine od gradnje školske zgrade." Što je navelo općinu Sv. Juraj da odustane od gradnje škole u Lukovu, nije nigdje izrijekom naznačeno.

Kada je završila školska godina 1898./99., školska je knjižnica raspolagala sa 75 djela za potrebe učitelja i 24 djela za potrebe učenika.

Na početku ovoga stoljeća polazak djece u školu neredovit je i nehajan. Da bi se to opravdalo, spominje se veliko siromaštvo toga kraja. Neprohodni putovi, zimske brige i sve ostalo sprečavaju dolazak djece u školu, a čim dođe proljeće, djeca s roditeljima odlaze u planinu čuvati blago. Često je mjesni župnik s propovjedaonice opominjao roditelje da redovito šalju svoju djecu u školu, ali se malo u tome uspijevalo. Preča su bila kućna zaduženja. Godine 1903. nastava se održava u kući Luke Rogića, puno prostranijoj i modernijoj zgradi od dotadašnje, a s djecom je trebala raditi učiteljica Ruža Kolačević, koja se zahvalila te iste godine i na njeno mjesto je Kraljevsko-županijska oblast u Gospiću imenovala učiteljicu Josipu Polić.

Prvi se put spominje peti razred školske godine 1906./07. u koji idu samo dva učenika.

Kada su u lipnju 1908. održani završni ispiti, stoji u Kontrolnoj knjizi, da su djeca dobro znala, "pisati, pismene radnje i crtanje su dobro uspjeli, a tako i mehaničko čitanje, nu trebat će lijepom čitanju priklanjati više pažnje, odučavanju djece od neobičnog naglašavanja". Na kraju nakon završnih ispita pred roditeljima su pročitana imena najboljih učenika. To je bio značajan poticaj i nagrada za uzorno ponašanje i odlično učenje.

Osobni život učiteljice Josipe Polić nije bio nimalo lak. Skromna zarada nije dopuštala nikakvo rasipništvo. Brinula je o svemu. $U$ dopisu što ga je uputila Općinskom poglavarstvu u Sv. Jurju pod rednim brojem 56 od 30. lipnja 1904. traži da se u "Iskazu troškova" ubilježi svota za drva kao i nagrada i stanarina mjesnoj učiteljici. U pisanom odgovoru na ovaj dopis Poglavarstvo iz Sv. Jurja 
iznosi stav "da je svota od 63 krune proračunom osigurana u ime drva škole, a ako se cijela svota ne potroši u gorerečenu drvarinu pripada općinskom poglavarstvu ostatak. Nagradu i stanarinu neka se samo škola u iskaz uvrsti". ${ }^{31}$

Zanimljiv je podatak koji se nalazi u dopisu Pučke škole Lukovo upućeno Slavnoj kraljevsko-kotarskoj oblasti u Senju 16. svibnja 1904. br. 33, u kojem učiteljica kaže "da u Lukovu nema analfabeta, jer otkad je škola ustavovljena ovdje mnogi se analfabet naučio čitati i pisati - malenkost koja bi se našla u Americi je". ${ }^{32}$

Da je zaista u to vrijeme učiteljima bilo teško i da su skromno živjeli, govori podatak zabilježen u Ljetopisu škole da je negdje koncem prosinca 1908. Prva hrvatska štedionica u Zagrebu darovala siromašnoj djeci u Lukovu 30 for. (14 učenika je dobilo nove opanke, a osam njih po jedan komad odjeće). Visoka zemaljska vlada darovala je ovoj školi zemljovid Austrougarske Monarhije, magnetnu iglu, magnetnu potkovu i stakleni štap.

Učitelj u Lukovu pred Prvi svjetski rat teško je živio. Da bi preživio, morao je katkad i prosjačiti, jer je prosjačenje u Podgorju bila normalna pojava. Uza starije osobe prosjačili su i mladi, najčešće djeca. Za novogradnju pučke škole u Lukovu 1910. godine je Kraljevsko-zemaljska vlada u Zagrebu odobrila 12000 kruna. Iako se temeljito vodio ljetopis u školi, nigdje ne nalazimo podatak kada je počela gradnja škole i kada je ona dovršena. Po svoj prilici je nekoliko listova istrgnuto u Spomenici, i to između školske 1910. i 1914. godine, jer tu vlada jedna nelogičnost, a prije i poslije toga uredno se svake godine vodi evidencija s potpisom učitelja. Je li u tom vremenu izgrađena školska zgrada?

\section{ŠKOLA U LUKOVU OTOČKOM IZMEĐU DVA RATA}

Početkom očekivanoga Prvoga svjetskog rata prilike su se temeljito izmijenile. Za učitelja dolazi Aleksandar Vareša, za koga može biti karakteristična izjava onodobnoga kraljevsko-županijskog školskog nadzornika:" Zapt dobar, djeca zdrava i čista, školska soba uredna." ${ }^{33}$ Za djecu i za čitav taj kraj nastaju teška vremena. Polazak djece u školu je vrlo slab. Nešto kasnije zatvaraju se redom škole u Hrvatskom primorju pa onda i u Lukovu Otočkom.

\footnotetext{
${ }^{31}$ Dopis Pučke škole Lukovu od 30. lipnja 1904.upućeno Općinskom poglavarstvu Sv. Juraj potvrđuje teško stanje učitelja. M. RAGUŽ, 1990, 291-298.

${ }^{32}$ Dopis škole Lukovo i Kotarskoj oblasti u Senju o analfabetima u Lukovu, od 16. svibnja 1904. (Pismohrana Osnoven škole S.S. Kranjčevića Senj.)

${ }^{33}$ Ova pedagoška opaska zapisana je u Kontrolnoj knjizi Pedagogijsko-didaktičke naravi u Pučkoj školi Lukovu, 1895.
} 
Godine 1915. samo zakratko djecu uči Kata Štefanec, a nastavu pohađa 46 učenika. Te ratne godine za učitelja su bile iznimno teške. Uz ratne brige i nedaće stigla je i oskudica. Školske vlasti slabo su slale pomoć. U proračunu od 5. veljače 1915. pod rednim brojem 442. u Nižoj pučkoj školi u Lukovu stoji sljedeće: "Na današnjoj sjednici reducirane su slijedeće stavke:1. za siromašnu djecu školske knjige na 60 kruna, 2. drva za učitelja 100 kruna. Neka naslov proti tome svoje prigovore sastavi i u roku 8 dana ovom Poglavarstvu podnese." Dvadeset dana nakon toga slijedio je prigovor u kome učitelj iznosi da svota od 100 kruna za drva ne može zadovoljiti, i to zato što mu prema službenom mjestu pripada 6 hvati ogrjevnih drva. Hvat drva u redovitoj najnižoj cijeni stoji 28 kruna. Stoga učitelj prijeti ukoliko mu ne udovolje zahtjevu da će otići iz kraljevsko-županijske oblasti. U Podgorju je 1918. kilogram žita stajao 10 kruna, a metar obične tkanine 100 kruna. Snalažljiviji su odlazili u Slavoniju i tamo radom pomagali članove svoje obitelji da prežive. I dalje je u to vrijeme polazak djece u školu bio vrlo slab. Gotovo polovica obveznika nije pohađala nastavu, pa stoga i sam rad ne zadovoljava tadašnje zahtjeve.

Između dva rata u školama su učitelji pedagošku dokumentaciju vodili latiničnim pismom, ali se paralelno u dokumentima vodila i ćirilično. Tako, primjerice, u svjedodžbama nazivi predmeta vode se latinicom i ćirilicom. To je i školski zakon dopuštao. Evo, koji su se predmeti učili u četvrtom razredu Državne narodne mješovite osnovne škole (tako se onda zvala škola koju su pohađali dječaci i djevojčice): Nauka o vjeri s moralnim poukama, Narodni (srpskohrvatski-slovenački) jezik, Narodna povijest s najznamenitijim događajima iz opće povijesti, Zemljopis naše države s osnovnim poznavanjem drugih zemalja, Računstva sa osnovama geometrije i geometrijskog crtanja, Poznavanje prirode, Praktična privredna znanja i umijenja, Ručni rad muški i ženski s naročitom primjenom narodnih motiva, Crtanje, lijepo pisanje, pjevanje i tjelesne vježbe po sokolskom sistemu. Pisani dokument o završenom razredu nosio je naziv Svjedočanstvo-svedočanstvo (ćirilica).

Premda su sve škole u senjskom Podgorju okupljale djecu i podučavale ih pismenosti, mnogi su ostajali bez naobrazbe, jer je broj obveznika bio daleko veći od broja polaznika. Izlaskom knjige "Čitanka za odrasle abecedarce" na samome početku dvadesetoga stoljeća, hrvatsko-kotarski predstojnik u Senju izvješćuje pučku školu u Lukovu da se organiziraju tečajevi čitanja i pisanja za odrasle. Visoka kraljevsko-zemaljska vlada u Zagrebu, Odjel za bogoštovlje i nastavu, izdaje 13. veljače 1904. pod rednim brojem 2562. sljedeću naredbu: " Nakladom Kraljevsko-zemaljske vlade Odjela za bogoštovlje i nastavu u Zagrebu izašla je knjiga "Čitanka za odrasle abecedarce" s namjerom da se školske dobi odmaklim 
Tab. 2. Broj učenika u opetovnici u Lukovu od 1920. do 1930. godine

\begin{tabular}{|c|c|c|c|}
\hline \multirow{2}{*}{ Šk. god. } & \multirow{2}{*}{ Broj učenika } & \multicolumn{2}{|c|}{ Spol } \\
\cline { 2 - 4 } & & $\mathrm{M}$ & $\check{Z}$ \\
\hline $1920 . / 21$. & 10 & 5 & 5 \\
\hline $1921 . / 22$. & 6 & 4 & 2 \\
\hline $1922 . / 23$. & - & - & - \\
\hline $1923 . / 24$. & 13 & 9 & 4 \\
\hline $1924 . / 25$. & 18 & 11 & 7 \\
\hline $1925 . / 26$. & 24 & 17 & 5 \\
\hline $1926 . / 27$. & 17 & 12 & 6 \\
\hline $1927 . / 28$. & 16 & 10 & 5 \\
\hline $1928 . / 29$. & 11 & 6 & 5 \\
\hline $1929 . / 30$. & 11 & 6 & \\
\hline
\end{tabular}

ljudima olakoti naučenje u čitanju." Prema ovoj naredbi pučki su učitelji imali zadaću da s ostalim mještanima koji su znali čitati i pisati organiziraju i da obuhvate što veći broj nepismenih u tečajeve opismenjivanja. Taj je rad bio na dobrovoljnoj osnovi. Mjerodavne vlasti proslijedile su im za ovo područje 2000 primjeraka tih čitanki. Ovo je područje imalo i do 80 posto nepismenih pa je akcija analfabetskih tečajeva bila vrlo ozbiljna. Pri popisu nepismenih svaki je morao reći koliko je voljan pridonijeti učitelju za njegov trud, kao i to hoće li, možda, bez učitelja uz upute ukućana moći naučiti čitati i pisati. Isto tako učiteljsko se osoblje moralo izjasniti u koje će vrijeme i uz koje uvjete poučavati odrasle analfabete. U mjestima gdje nema učitelja, a nalazi se župnik ili paroh, također treba provoditi tu aktivnost. "Kako je obučavanje analfabeta vrlo važno pitanje za narod županije ličko-krbavske, očekuje kraljevsko-županijska oblast da će učitelji i svi ostali prijatelji kulturnog napretka našega naroda pripomoći oblasti u njezinu nastojanju da se ovo pitanje rieši na korist prosvete i naroda". ${ }^{34}$

U poratnim godinama, ali i prije rata, u Lukovu je radila i opetovnica. Ovu nastavu redovito su pohađali učenici i njihov se broj kretao između 10 i 20, katkad ih je bilo manje, ovisno o broju djece koja su se nalazila u selu i bliže školi, a nisu namjeravala ići na daljnje školovanje. Roditelji su i u ovim prilikama radije djeci davali kućanske poslove. Opomene koje je upućivao učitelj ili svećenik malo su koristile. Borba za goli život bila im je važnija stvar.

S kopnene strane u Lukovo je teško doći i dosta je nepristupačno. Djeca su morala dolaziti iz udaljenih sela i zaselaka, a kada je otvorena škola u Donjoj

${ }^{34}$ Dopis Kraljevsko-županijske oblasti u Gospiću, 1904. 
Kladi 1929./30. djeca iz Zagona i Donje Klade idu u nju. Broj obveznika u Lukovu sada je opao za dvanaest učenika. Teškoće je činila općina koja se nije na vrijeme brinula oko osiguranja učeničkog pribora, knjiga i svih ostalih školskih potrepština. Stanje se popravlja kada za učitelja dolazi već spomenuti Ivan Pavelić. Nakon njega smjenjuju se zaredom: Tinko Škubić, Franjo Mladenić, Vazmoslav Barbelić i Slavica Jelić.

Školske godine 1941./42. bila je za sve vrlo teška i nesigurna. Nastava je bila prekinuta preko pet mjeseci (od 25. studenoga 1941. do 5. svibnja 1942.). Pri posjeti i pregledu škole kotarski školski nadzornik Nikola Šimunić, a na temelju Uredbe Ministarstva nastave br. 20.008. utvrdio je da djeca neće moći u starije razrede jer je bio velik prekid u radu. Djeca su tako morala ponoviti školsku godinu. I sljedeća školska godina nije bila ništa bolja. Nastava je počela 3. veljače 1943. zbog bolesti učiteljice Marije Žvanović. Upisano je 55 učenika, a pohađalo ih je samo 27. Smetnji u nastavi je bilo mnogo, a učiteljica izdvaja: slabu ishranu, neredovito pohađanje nastave, vremenske nepogode i premalo učila u školi. U ožujku 1944. ponovo za učitelja u Lukovo dolazi Ljudevit Fuks iz Sv. Jurja. Iza njega 21. svibnja 1945. godine dolazi Ruža Babić, učenica 7. razreda gimnazije, kao pomoćna učiteljica. Samo nekoliko dana kasnije u Lukovo dolazi za učitelja Matija Štokić sa završenim učiteljskim tečajem. Tako nastaje novo razdoblje u povijesti hrvatskog školstva, pa i povijesti ovih podvelebitskih seoskih škola.

\section{PUČKA ŠKOLA OLTARI}

Prema odredbi članka 24 Školskog zakona od 14. listopada 1874. i članka 23. Školskog zakona od 31. listopada 1888. u svakom mjestu s barem 40 školskih polaznika morala se otvoriti opća pučka škola. Sukladno tim zakonskim odredbama u Oltarima se otvara škola 1904. U Spomenici za župu Sv. Juraj 1903.godine piše da je izgrađena zgrada osnovne škole u Oltarima, a u jesen 1904. škola je blagoslovljena i otvorena za nastavu. ${ }^{35}$

Prva učiteljica je bila Anka Lovinčević i službovala je svega pet mjeseci jer nije imala gdje stanovati. Pri školi nije izgrađen učiteljski stan, pa je učiteljica Lovinčević morala stanovati kod lugara Mate Samaržije u jednoj prostoj graničarskoj kući koja je bila pogodna kojekakvim neprikladnim zgodama. Iza nje je za učitelja došao Mate Majer iz Švice, poznati učitelj i dugogodišnji prosvjetni djelatnik u Sv. Jurju. Koliko je radio u Oltarima nije nam poznato, jer je godine 1907. došao kao pripravnik u Sv. Juraj.

${ }^{35}$ M. RAGUŽ, 2008, 89-92. 
Ovu su školu polazili učenici iz zaselaka: Tuževac, Rakita, Turinski Krč, Marenići, Pandore, Glavaši, Rukavine, Krstače, Jude, Babić Dolac, Razbojište, Matešić Pod, Orije i Osredak. Je li u prvo vrijeme njihov broj prelazio četrdeset, nemamo podataka o tome. Samo je sačuvan Glavni imenik Oltari od godine 1947. ${ }^{36}$ i jedan Urudžbeni zapisnik iste godine. Teško je na temelju tih skromnih podataka rekonstruirati povijesni razvitak ove škole i navesti relevantne činjenice za tu prosvjetnu ustanovu.

Poznato je da su učenici ovih zaselaka polazili i školu u Sv. Jurju, jer su njihovi roditelji selili za vrijeme zime u Primorje, a na proljeće ponovno se vraćali u planinu, i ne samo zato. Ova škola je dijelila sličnu sudbinu ostalih škola na senjskom području: često je prestajala s radom zbog pomanjkanja učitelja. Povremeno je ista učiteljica znala raditi u svojoj matičnoj školi prije podne, a poslije podne i u ovoj školi.

Školske godine 1941./42. u školi je radila učiteljica Mira Molnar. U Glavnom imeniku stoji da je učiteljica Zlata Adamović radila godine 1947., a spominje se i Ksenija Frančišković, koja radi samo kratko vrijeme. Već školske godine 1948./49. nalazimo ime Petra Polonijo. Od 1950. do 1952. radila je Petra Miškulin. Je li to ista osoba od godine 1948., nema podataka u školskoj dokumentaciji. Od 1952. do 1954. radi u ovoj školi Marica Anić, a iza nje učiteljica Dragica Turina. U Školskim propisima od godine 1955. na strani 692. stoji da su u šestorazrednoj školi u Oltarima radile učiteljice Petra Miškulin i Dragica Turina. Više godina u ovoj školi je radio Pero Biondić i s njim Slavica Biondić. Taj bračni par radi od 1956. do 1960. Svojim učenicima i njihovim roditeljima ostali su u lijepoj uspomeni. Tih godina radili su još Gita Biondić i Slavica Krmpotić. Jedno vrijeme (1962./63.) ovdje je radila i učiteljica Slavica Gašljević-Babić. Tako završava jedno školsko razdoblje u kojemu su sve škole na senjskome području djelovale samostalno. Do tada je senjsko školstvo djelovalo vrlo uspješno i uspijevalo održavati gotovo na cijelome području brojno žiteljstvo tu, gdje jesu i gdje su im korijeni. Od tada postupno školska politika značajnije pridonosi ideji raseljavanja, migraciji i potrazi za boljim životom ionako osiromašenog podgorskog seljaka - radnika.

Od godine 1960. Osnovna škola Oltari postaje područna škola i administrativno i pedagoški pripada središnjoj školi u Sv. Jurju. Nastaje teško stanje tih malih škola, s malo đaka. Kao područni odjeli, premalo su dobivali, da bi se kvalitetnije razvijali i da bi zadržavali ne samo nadolazeće učenike,

${ }^{36}$ U Pismohrani Osnovne škole S.S. Kranjčevića Senj nalazi se sačuvani jedini dokument Glavni imenik učenika škole Oltari, 1947. M. RAGUŽ, 2008, 89-92. 
već i postojeće učitelje. Sličnu sudbinu dijelila je i ova škola. Primjerice, u zapisniku prilikom pedagoškog pregleda od godine 1964./65. kada su radili Marija Vukelić i Đorđe Pavlović, školska zgrada se nalazila u derutnom stanju, a školski namještaj bio je manjkav i trošan te nije bio primjeren starosnoj dobi osnovnoškolske djece. To jadno stanje još je više pogoršala politika obrazovanja na senjskom području koja je naglasak stavljala na jačanje središnjih škola, a zanemarivala područne škole. Dosta slaba situacija bila je i na području obrazovanja. $U$ tom istome zapisniku stoji da se učitelj nikako ne priprema za nastavu, ne razrađuje se ni tjedni, a ni mjesečni planovi nastavnog rada. U jednom drugom zapisniku (17. ožujka 1964.) piše da je niska odgojnoobrazovna razina znanja učenika. To je rezultiralo i velikim brojem negativno ocijenjenih učenika na kraju školske godine. Sljedeće školske godine nalazimo u tim podatcima da je u školi radio Augustin Tomljanović, a godinu dana kasnije ponovno se spominje Đorđe Pavlović i Danica Miškulin. Od godine 1971. pa sve do 1977. kada je i škola zatvorena u njoj radi učitelj Joso Penavić. Sigurno je da je u ovoj školi radilo mnogo više učitelja, ali nažalost o njima nemamo podataka. Usmena kazivanja nisu vjerodostojna i često su proturječna, pa ih autor nije uzimao u obzir.

Škola prestaje s radom godine 1977. kada je ostalo svega šest učenika u sva četiri razreda. Zgrada ostaje na milost i nemilost vremenu, a preostali učenici putuju u Sv. Juraj. Putovanja u središnju osnovnu školu u Sv. Juraj nisu bila nimalo laka, pa su i roditelji teško pristajali na takve uvjete školovanja svoje djece. Bilo je mnogo otpora, mnogo izostajanja i mnogo početnih poteškoća. Školska zgrada uza samu cestu prema Krasnu danas služi kao planinarska kuća i ništa nije izgubila od vanjskog izgleda. Njezino održavanje je skromno, ali i ovakvi postupci bar donekle pridonose da se te napuštene školske zgrade održe.

\section{PUČKA ŠKOLA U STARIGRADU}

Ovdje se iznose do sada nepoznate činjenice od početka rada škole u Donjem Starigradu, iako se nigdje izrijekom u školskoj dokumentaciji ne spominje "Gornji" ili "Donji", već samo Starigrad. Ta škola u Starigradu primala je djecu iz naselja Bralići, Devčići, Ivanča, Modrići, Rogići, a vjerojatno i djecu iz još nekih naselja koja su dolazila u školu po želji svojih roditelja. Ni sva djeca iz spomenutih škola u bližim selima i zaseocima nisu polazila školu iako ih je na to obvezivao zakon, jer je gotovo uvijek broj djece koja su trebala pohađati školu bio veći od broja novoupisanih, a gotovo svaka škola bilježi teškoće u svome svakodnevnome radu zbog neredovitog pohađanja nastave. 
U Imeniku (matica) za niže pučke škole u Starigradu među podatcima o otpuštenoj djeci od 1. rujna godine 1900. stoji na prvoj stranici pod rednim brojem 1:" Učenik Mijo Babić završio treći razred na temelju privatnog poučavanja i provedenog ispita." Dakle, taj učenik nije upisan u prvi razred, iako je škola u tom mjestu tek otvorena. ${ }^{37}$ Te godine upisana su još četiri učenika: Ivan Devčić, Ivan Dragičević, Božo Grbac i Martin Legac, koji su otpušteni godine 1905. Redni brojevi u Imeniku prepravljani su crvenom olovkom i ubilježena je druga godina, pa to donekle zbunjuje i izaziva određene dvojbe pri utvrđivanju točnih podataka.

Pod rubrikom godine (kada je učenik polazio školu) ubilježene su neke druge godine, što upućuje na zaključak da su ti učenici prije polazili školu negdje drugdje (najbliža im je bila škola u Lukovu), a ovdje u Starigradu nastavljali i završavali pučku naobrazbu.

Kako je u školi glavni imenik ili glavna knjiga temeljni dokument, i ova starigradska glavna knjiga morala bi biti pouzdana, ali nažalost nije. Zapravo, nema svih podataka relevantnih za upis djece u školu. Tako je, primjerice, na prvoj stranici ispravljeno da je školska godina počela godinom 1904., pa tako redom. Školske godine 1914./15. upisan je samo jedan učenik, i to Luka Dragičević, pod rednim brojem 1/328. Broj 1 je tekući broj, a broj 328 je broj glavnog imenika. To upućuje da je taj učenik upisan prije u neku drugu knjigu. Na temelju tih činjenica može se zaključiti da je ova jedina sačuvana temeljna knjiga vrlo površna i nepotpuna. U sredini imenika istrgnuto je nekoliko listova, a pri kraju same knjige vođena je evidencija pisanih dopisa koje je školi uputio Kotarski narodni odbor 31. kolovoza 1945. Bilježile su se npr. naplate takse, obavijesti o dječjem tjednu, vjeronauku kao predmetu u osnovnoj školi, suzbijanju pjegavca itd. I tako sve do sredine kolovoza 1946. zasigurno nije bilo papira na kojem će se bilježiti potrebne stavke o stanju u toj školi?

Prvi učitelj bio je Josip Gračan. Iza njega dolazi Danica Petrović koja je radila i u Lukovu. Škola je radila bez prekida, iako je za vrijeme Prvoga svjetskog rata bilo dosta siromaštva, gladi i stradanja u cijelome ovom području podno Velebita. U spomenutu knjigu upisana su od 1914. do 1918. godine svega dva učenika. Taj podatak govori mnogo o prilikama u školi, u mjestu, u razmišljanjima mještana i o samoj sigurnosti slanja te djece u školu. Razdoblje od 1909. pa do 1912, nije uopće evidentirano u Imeniku, a kako nema drugih sačuvanih dokumenata, postoje i dvojbe oko toga je li škola u to vrijeme uopće

${ }^{37}$ U Osnovnoj školi S. S. Kranjčevića Senj sačuvan je jedini dokument Imenik ( matica) učenika škole Starigrad. M. RAGUŽ, 1995, 369-378. 
radila. Do učitelja se vrlo teško dolazilo pa su se na senjskome području škole povremeno zatvarale.

Godine 1909. škola u Starigradu imala je 13 polaznika, a te godine učiteljica Danica Petrović radi u Lukovu. Sljedeće školske godine nema zabilježenih podataka o polaznicima, ali u Lukovu se redovito održava nastava. Sve do 1941. godine brojno stanje učenika u Imeniku je nepotpuno i podatci su manjkavi, odnosno neke su rubrike potpuno prazne. Budući da je u blizini u Lukovu pučka škola djelovala bez prekida, moguće je da je i ova u Starigradu imala sličnu sudbinu. Između dva svjetska rata ova je škola nosila naziv Državna osnovna škola u Starigradu. Kada je završio Drugi svjetski rat, njezin je rad nastavljen u Gornjem Starigradu.

\section{PUČKA ŠKOLA U PRIZNI}

Godine 1908. otvorena je škola u Prizni. Ovu su školu polazili učenici iz Prizne i brojnih okolnih naselja sve do Karaule. Školska zgrada je izgrađena za potrebe škole na krševitom području do koje se teško dolazilo pješice. Uz nju je sagrađen i stan za učitelja. Za mnoge druge školske zgrade u kojima se nastava držala nemamo sačuvanih podataka i o njima malo znamo, gotovo ništa. Takve su škole u Donjoj Kladi, Dundović Podu i Dušikravi. O ovoj u Prizni ne znamo ništa sve do 1946. godine. Kao i sve druge škole na ovome području, i u Prizni se škola razvijala od male četverorazredne pučke škole sve do osmorazredne osnovne škole (uključujući godišnje i do 70 učenika u svim razredima), ali je doživjela pad onom spomenutom reorganizacijom iz godine 1959., kada se stariji razredi sele u središnju Osnovnu školu u Jablanac. Pučka škola u Prizni nekoliko puta je mijenjala svoj naziv. Najprije se zvala Narodna škola u Prizni, zatim Šestogodišnja škola u Prizni i poslije Osmogodišnja škola, a na kraju imala je naziv Područna škola Prizna. Zatvorena je godine 1977.

Tab. 3. Učitelji koji su radili u Prizni u razdoblju od 1946. do 1977. godine

\begin{tabular}{|l|l|l|l|}
\hline 1. URŠULA DRAGOVIĆ & $1946 .-1948$. & 9. BRANKO ŠPALJ & $1957 .-1960$. \\
\hline 2. FRANJO FILIČIĆ & $1947 .-1948$. & 10. MILAN HRVOJ & $1957 .-1959$. \\
\hline 3. MARIJA GAŠPAROVIĆ & $1948 .-1952$. & 11. JOSIP LOPAC & $1957 .-1958$. \\
\hline 4. ZLATA STANIĆ & $1950 .-1953$. & 12. JOSIPA STARČEVIĆ & $1957 .-1965$. \\
\hline 5. MARICA MARINAC & $1953 .-1955$. & 13. DRAGICA ROC & $1958 .-1959$. \\
\hline 6. NEVENKA PAVELIĆ & $1955 .-1957$. & 14. Z. GREČEVIĆ & $1961 .-1963$. \\
\hline 7. MILAN BABIĆ & $1955 .-1956$. & 15. DRAGICA MARTULAŠ & $1965 .-1969$. \\
\hline 8. JOSIPA SOMEK & $1956 .-1957$. & 16. ANA MARAS & $1969 .-1977$. \\
\hline
\end{tabular}




\section{OSNOVNE ŠKOLE U DONJOJ KLADI, DUNDOVIĆ PODU} (GRABARJU) I DUŠIKRAVI

Zbog manjkave školske dokumentacije sve tri škole prikazane su zajedno. Iako su sve tri škole pojedinačno mnogo značile za mjesta u kojima su svojedobno djelovale, nismo mogli ništa više napisati o njima.

Godine 1929. u Donjoj Kladi otvorena je škola. Sve što imamo sačuvano u školskoj pismohrani o radu te škole jest Glavni imenik učenika, koji je necjelovit. Naime, listovi su bez reda istrgani, popisi godina upisa djece neusklađeni prema rubrikama, godišta bez potpisa učitelja, tako da je vrlo teško vjerodostojno rekonstruirati razvoj i djelovanje te škole. Od početka godine 1929. pa sve do 1949. u Glavnom imeniku upisano je 212 učenika. Ne možemo tvrditi da je te godine zatvorena škola, jer o tome nema pisanoga traga. Ni gradska pismohrana ne raspolaže bilo kakvim dokumentima o toj školi.

Tab. 4. Učitelji koji su radili u Donjoj Kladi u razdoblju od 1929. do 1949. godine

\begin{tabular}{|l|l|l|l|}
\hline 1. FRANJO OŽANIĆ & $1929 .-1936$. & 4. MATIJA ŠTOKIĆ & $1941 .-1948$. \\
\hline 2. ANKA PAVELIĆ & $1936 .-1941$. & 5. TOMO FUTAČ & $1948 .-1949$. \\
\hline 3. BOGOSLAVA STAŠIĆ & $1941 .-$ & & \\
\hline
\end{tabular}

Tab. 5. Brojno stanje učenika u Dundović Podu u razdoblju od 1946. do 1959. godine

\begin{tabular}{|l|r|r|r|r|r|r|}
\hline \multicolumn{1}{|c|}{ Šk. god. } & I. & II. & III. & IV. & V. & ukupno \\
\hline $1946 . / 47$. & 21 & 2 & 4 & 2 & - & 29 \\
\hline $1947 . / 48$. & 4 & 17 & 2 & 3 & - & 26 \\
\hline $1948 . / 49$. & 7 & 9 & 15 & 2 & - & 33 \\
\hline $1949 . / 50$. & 3 & 7 & 8 & 13 & - & 31 \\
\hline $1950 . / 51$. & 5 & 4 & 7 & 8 & - & 24 \\
\hline $1951 . / 52$. & 6 & 4 & 5 & 7 & 6 & 28 \\
\hline $1952 . / 53$. & - & 7 & 2 & 5 & - & 14 \\
\hline $1953 . / 54$. & 3 & - & 9 & 4 & - & 16 \\
\hline $1954 . / 55$. & 3 & 3 & 4 & 6 & 8 & 24 \\
\hline $1955 . / 56$. & 5 & 2 & 2 & 3 & 5 & 17 \\
\hline $1956 . / 57$. & 5 & 5 & 3 & 3 & 8 & 24 \\
\hline $1957 . / 58$. & 1 & 3 & 4 & 3 & - & 11 \\
\hline $1958 . / 59$. & 1 & 3 & 3 & 5 & - & 12 \\
\hline
\end{tabular}

Tab. 6. Učitelji koji su radili u Dundović Podu u razdoblju od 1941. do 1954. godine

\begin{tabular}{|l|l|l|l|}
\hline 1. IVAN MAKEK & $1941 .-$ & 4. MARIJA SKORUP & $1951 .-1952$. \\
\hline 2. RUŽA MARKUŠIĆ & $1946 .-1948$. & 5. ANTONIJA PERAKOVIĆ & $1951 .-1954$. \\
\hline 3. STJEPAN MRŠIĆ & $1948 .-1951$. & & \\
\hline
\end{tabular}


Tab. 7. Učitelji koji su radili u Dušikravi u razdoblju od 1947. do 1962. godine

\begin{tabular}{|l|l|l|l|}
\hline 1. MATE MRŠIĆ & $1947 .-1951$. & 6. ANKICA LJEŠKO & $1955 .-1957$. \\
\hline 2. VLADIMIR JURČENKO & $1951 .-1952$. & 7. A. JUŠIĆ & $1957 .-1958$. \\
\hline 3. MARICA MARINAC & $1952 .-1953$. & 8. & \\
\hline 4. MATE KOVAČEVIĆ & $1953 .-1954$. & 9. DOROTEA? & $1961 .-1962$. \\
\hline 5. BORIS OŽURA & $1954 .-1955$. & & \\
\hline
\end{tabular}

U Dušikravi je djelovala pučka škola od 1947. pa sve do 1961. ili 1962. godine. To je podatak prema Glavnom imeniku. U njegovu je popisu 110 učenika s nekoliko učitelja ( vidi popis učitelja). Spomenuti imenici čuvaju se u školskoj pismohrani, i svi su izgledi da je to jedina sačuvana dokumentacija o tim školama. Mnogi učitelji koji su radili u tim malim podgorskim školama iza sebe nisu ostavljali nikakve pisane tragove. Ali, i to je značajno što smo naveli, jer smo ipak, usprkos svemu, tako sačuvali uspomenu na njih, na jedno vrijeme i na njihovo prosvjetno djelovanje.

Glavni imenik učenika škole u Dundović Podu (Grabarju) ima popis učenika od 1946. pa do 1959. U popisu ove knjige s pet učitelja koji su radili na toj školi. Druge školske dokumentacije nema. Školske godine 1951./52. radila je učiteljica Marija Skorup u Dundović Podu s 21 učenikom (u prvom razredu 8 učenika i drugom 13 učenika).

\section{OSNOVNA ŠKOLA VLAKA}

Premda o ovoj školi nema sačuvanih dokumenata, ipak sam u pismohrani Osnovne škole S. S. Kranjčevića u Senju pronašao Imenik učenika u kojemu sam našao imena učitelja koji su radili od 1948. godine, a u popisu su 152 učenika. U ovu školu su polazili nastavu učenici s područja Živi Bunari, Miškovići, Jurkuša i šire. Kada je otvorena, do kada je radila, ostaje za sada nepoznato. U jednom dokumentu ravnatelja škole Sv. Juraj ( 17. 11. 1967.) zabilježeno je da je ta škola zatvorena 1968. S obzirom na to da je izvješće ravnatelja pisano 17. 11. 1967., a škola zatvorena 1968. ostaje dvojba oko toga podatka. Nakon školske godine 1961./62. o ovoj školi nema podataka osim da je te školske godine bilo ukupno 26 učenika (I. razred 7 učenika, II. razred 5, III. 5 i IV. razred 9 učenika). Jedino se spominje učiteljica Katica Crnić (školske godine 1962./63.), i da je imala 11 učenika. Dakle, škola je radila i nakon prve reorganizacije školske mreže na senjskom području jer je bilo učenika. Na temelju ovih podataka, može se ipak zaključiti da je zatvorena godine 1968. (u školskoj dokumentaciji nije zabilježeno kada je zatvorena). 
Tab. 8. Učitelji osnovne škole Vlaka

\begin{tabular}{|l|l|l|l|}
\hline 1. OSKAR AMANČIĆ & $1948 .-$ & 4. BLAŽENKA ČUBRIĆ & 1955.-1956. \\
\hline 2. LAZAR DUDIĆ & $1948 .-1950$. & 5. ŠTEFICA SLOVIĆ & $1956 .-1959$. \\
\hline 3. NEVENKA PAVEŠIĆ & $1950 .-1955$. & 6. KATICA CRNIĆ & (oko 1962./63.) \\
\hline
\end{tabular}

Napomena: Opširnije o četverorazrednim osnovnim školama u senjskom Podgorju, te o učiteljima i učenicima vidi u knjizi M. Raguž, Školstvo senjskog Podgorja, 2008, 130-135.

\section{Zaključna razmatranja}

Pučke škole u Sv. Jurju i Jablancu najstarije su škole u senjskom Podgorju koje su se tijekom svoje povijesti razvile od jednorazrednih i dvorazrednih u središnje osmorazredne osnovne škole te su prije pedesetak godina doživjele najveći svoj uspjeh, okupljajući od prvih do osmih razreda i po nekoliko stotina učenika. Škole su bile glavna žarišta prosvjete i kulture u tim mjestima. S obrazovanim učiteljima i izvrsnim učenicima često su i izvan škole u životnim okolnostima pripremali i priređivali različite obrazovne manifestacije i time neposredno pridonosili jačanju temeljne kulture među svojim mještanima. Učitelji su, osim svojih učiteljskih obveza, svojedobno radili i na prosvjećivanju i opismenjivanju onih osoba koji su iz bilo kojih razloga ostali bez temeljne naobrazbe, bez poznavanja pisma. Neredovitom školovanju najviše je pridonosila bijeda i neimaština podgorskih seljaka, pa je roditelju više značilo ako je dijete otišlo za stokom ili u polje raditi, nego da je u školi s učiteljem. I ne samo to. Premalo je mogućnosti da se dijete opremi za školu, s knjigama i školskim priborom, jer je prosjačenje imalo prioritet. Usprkos tome škole se otvaraju, djeca se školuju, a nepismenost postupno ustupa mjesto znanju, kulturi i višoj kvaliteti života.

Već u vrijeme osnivanja osmorazrednih škola mjerodavni politički i prosvjetni čimbenici Grada Senja zajedno sa školskim predstavnicima zagovaraju osnivanje šest školskih središta, od kojih su dva u Podgorju, i to Osnovna škola Sv. Juraj kojoj bi pripadale područne škole u Lukovu, Oltarima, Bilopolju, i Hrmotinama te Osnovna škola Jablanac kojoj bi pripadale područne škole u Dušikravi, Prizni, Dundović Podu (Grabarje), Gornjem Starigradu i Vlaki. Školski prostor je manjkao, pa su se odgovorni u školama snalazili na najrazličitije načine. Primjerice, u Sv Jurju se nastava održavala nakon te prve reorganizacije školske mreže, u postojećoj školskoj zgradi, vatrogasnom domu i bivšoj zgradi žandarmerijske postaje. To je bilo dodatno opterećenje za nastavni proces, za opremanje školskog prostora učilima, ali i svim drugim materijalnim sredstvima potrebnim za izvođenje nastavnoga procesa. 
Nakon prve reorganizacije škola u Podgorju su zatvorene ove škole: Donja Klada (1949.), Brisnice (1959.), Dundović Pod (Grabarje, 1959.) i Dušikrava (1961). Nije prošlo mnogo vremena, a prosvjetne vlasti rade na drugoj reorganizaciji škola (1967.), nastojeći najprije oformiti jednu središnju školu sa sjedištem u Senju, dok bi sve seoske škole bile pretvorene u područne odjele. Takva organizacija školstva funkcionirala je samo godinu dana pa su 1969./70. oformljene dvije središnje škole: jedna sa sjedištem u Senju a druga sa sjedištem u Sv. Jurju (ova je imala sve druge područne škole na cijelom senjskom području). U sljedećih deset godina zatvorene su škole u Hrmotinama (1971.), Oltarima (1977.) i Prizni ( 1977.). I konačno, 1. siječnja 1979. godine stvorena je jedinstvena osnovna osmorazredna škola sa sjedištem u Senju, a njezini područni razredni odjeli djelovali su kao osmorazredne ili četverorazredne škole do njihova konačnog zatvaranja. Ostala je samo ona u Sv. Jurju, kako je ranije spomenuto, sa svega 26 učenika. I u njoj danas vlada beznađe.

\section{Izvori}

BAS (Biskupski arhiv, Senj) - Spisi, Sv. Juraj, 1870.

BAS, Svezak FATA PAROCHIARUM, 1836.

Državni zavod za statistiku, Zagreb, 2003. i 2011.

Glavni imenik učenika škole u Oltarima

Glavni imenik učenika Pučke škole u Jablancu od 1892.

Glavni imenik učenika škole Donja Klada, 1929.

Glavni imenik učenika škole Dundović Pod, 1946.

Glavni imenik učenika škole Dušikrava

Glavni imenik učenika škole Vlaka, 1948.

Glavni Imenik učenika škole Prizna

Kontrolna knjiga škole u Lukovu

Ljetopis župe u Lukovu

Schematismus cleri diocesium Segnienzis et Modrušiensis sue Corbavienzis Segnie, 1905.

Spomenica župe Sv. Juraj

Spomenica osnovne škole Sv. Juraj

Spomenica župe Lukovo

\section{Literatura}

Franz BACH, Otočaner regimentsgeschichte, Karlstadt, 1855.

Josip BURIĆ, Biskupija senjska i modruška u XVIII. stoljeću, Gospić-Zagreb, 2002, 77. Antun CUVAJ, Građa za povijest školstva kraljevine Hrvatske i Slavonije od najstarijih vremena do danas, I, Zagreb, 1910. (drugo ispravljeno i popunjeno izdanje). 
Julije Franjo FRAS, Topografija karlovačke Vojne krajine, Gospić, 1835.

Marko PRANJIĆ, Autohtoni starorimski odgoj, Napredak, Zagreb, 2015, str. 169-203.

Mirko RAGUŽ, Pučka škola u Jurjevu, Senjski zbornik, 13, Senj, 1988, 215-224.

Mirko RAGUŽ, Iz povijesti školstva senjskog kraja, Senjski zbornik, 17, Senj, 1990, 291-298.

Mirko RAGUŽ, Školstvo senjskog Podgorja, Senj, 2008, 89-92.

Mirko RAGUŽ, Pučka škola u Jablancu, Senjski zbornik, 20, Senj, 1993, 195-200.

Mirko RAGUŽ, Pučke škole u Brisnicama, Gornjem Starigradu, Bilopolju, Senjski zbornik, 21, Senj, 1994, 315-320.

Pavle ROGIĆ, Naseljenost velebitske primorske padine kroz historiju, Senjski zbornik, I, Senj, 1965, 35-68.

Franjo TIĆAK, Kratka poviest o razvitku pučkog školstva u hrvatsko-slavonskoj Vojnoj krajini od najstarijih doba do danas, Zagreb, 1880.

Franz VANIČEK, Specialgeschichte der Mulitargrenze, II, Wien. 1875, 601-602.

\section{THE SCHOOLS OF SENJ PODGORJE}

Summary

Over the area of Senj Podgorje public education in the past was quite well developed, and so in almost all towns and settlements of local authority with the help of the competent political and educational institutions they first of all opened four-grade, then six-grade, and eight-grade elementary schools. Their educational activity depended mostly on the material and spatial possibilities, but later also on the number of attendees in individual settlements. The time from the opening to their final closure in some places was not long. About all of that will be briefly presented all the schools from their opening to their final cessation of work with all the relevant data to which I arrived at in the modest school documentation. I have written and published more thoroughly and in more detail about the public schools in a book entitled Školstvo senjskog Podgorja (Schooling of Senj Podgorje) published by Matica Hrvatska Senj, in 2008. They are more expertly and scientifically presented with all the details, schools, teachers and students in the 13, 17, 20, 21 and 22 issues of the Senj Zbornik. In additional research on this subject in preparation for a scientific meeting about Podgorje there is less of their data in this paper because all of Podgorje schools were thoroughly analysed previously.

Keywords: Podgorje, schools, first schools, teachers, students, standard of teachers, school closures 